\title{
DYAD MODEL AS A CARING INNOVATION IN HIGH RISK PREGNANCY
}

\author{
${ }^{1.2}$ Sri Wahyuni, ${ }^{3}$ Moses Glorino Rumambo Pandin \\ ${ }^{1}$ Doctoral Program, Nursing Faculty, Universitas Airlangga \\ ${ }^{2}$ Departemen of Maternitu Nursing, Nursing Faculty, Universitas Islam Sultan Agung \\ ${ }^{3}$ Departemen of English Literature, Faculty of Humanities, Universitas Airlangga
}

Coresponden Author: Sri Wahyuni

Email: sri.wahyuni-2020@fkp.unair.ac.id

\begin{abstract}
Background Pregnancy is a process of maturity for women that requires adaptation to the changes in their new roles. Adjustment to a new role is not easy, especially if the pregnancy is accompanied by risks, so it is necessary to get treatment to minimize complications. Dyad models that optimize husband or family support are very important to prevent the risk of complications and adapt mothers to their new roles. The purpose of this study was to determine the effect of the dyad model on high-risk pregnancies. The method used with a literature review is through the collection of articles from Scopus, ebsco, ProQuest and PubMed. The results obtained were articles from Scopus 9, Ebsco 107, PubMed 214 and ProQuest 85 which carried out identification, screening and eligibility for 25 articles. Overall results mention. Journals are categorized into 4 groups, Dyad Model and social support, high-risk pregnancy, maternal role and Self Efficacy. Conclusion, there is an effect of the dyad model on care for high-risk pregnancies.
\end{abstract}

Key Word: Dyad Model, Caring, High Risk Pregnancy

\section{Background}

Pregnancy is part of the process of female maturity which can cause changes in all body systems as well as have a psychological impact. Pregnancy does not always run normally, we often encounter pregnancies with a variety of risks that accompany it or are called high-risk pregnancies. Pregnancy with complications that can affect the health of both the mother and the fetus. Types of risk in pregnancy such as pregnancy with HIV positive, diabetes mellitus, hypertension in pregnancy, obesity, multiple pregnancies, pregnancy too young or too old, biological factors, social factors such as age, social status, parity, obstetric history, occupation, factors Psycho-social and nutritional status also influence health conditions during pregnancy ${ }^{1}$.

The incidence of high-risk pregnancy is a very dangerous condition and can increase both maternal and infant mortality rates. Data from WHO states that every day a number of 810 mothers die due to pregnancy and childbirth, $75 \%$ of them die due to complications that occur during the pregnancy period. ${ }^{2}$. The prevalence of high-risk pregnancies was $14.4 \%$. Based on the 
color-coded risk stratification, $7.5 \%$ of the women were categorized as red, $6.9 \%$ yellow, $72.0 \%$ green, and $13.6 \%$ white. Women with high-risk pregnancies were 4.2 times more likely to develop illnesses and other risky conditions during labor ${ }^{3}$.

High-risk pregnancies can cause various health problems for the mother and the fetus during the perinatal period. High-risk pregnancies with impaired blood pressure have the potential to because preterm labor and low birth weight as a result of hypoperfusion and decreased uteroplacental perfusion. Mothers who have a pregnancy with diabetes mellitus and a history of obesity are at the highest risk of experiencing complications in pregnancy ${ }^{4}$. Pregnancy with obesity and Diabetes Mellitus can also lead to complications in both the mother and the fetus. Complications can include hydramnios, preterm labor, severe hypoglycemic, diabetic ketoacidosia, hypertension in pregnancy, pre-eclampsia, labor dystocia, macrosomia and intensive neonates.

Mothers with pregnancy conditions that are full of risks are stressors in themselves but need adaptation to carry out their new roles as mothers who are very important in the care and development of babies or maternal attachments. Adjustment to this change in role is not an easy thing, especially when the pregnancy is a high-risk pregnancy that actually or has the potential to interfere with the health of both the mother and the fetus ${ }^{6}$. High-risk pregnancy with various health threats causes affects the psychological response of the mother. The mother will feel fear, sadness, feel guilty and sometimes even experience frustration throughout her pregnancy ${ }^{7}$. This condition will increasingly have a negative impact on the health of the mother and the fetus and affect the mother's ability to adapt to her new role.

Women who are not ready to become mothers will feel depressed and helpless starting from pregnancy, pregnancy, delivery and during the care of the baby in their new role. Barriers that help a woman in carrying out her role will have an impact on the inability to become a mother who can cause stress or depression while carrying out her new role which will also have an impact on the growth and development of the child ${ }^{8}$. As for the research conducted by ${ }^{9}$ Which states that failure to become a mother can lead to depression and have an impact on the ability of mothers to maintain pregnancy and child care. The mother's ability to adjust roles and manage problems can reduce various problems experienced during her pregnancy period ${ }^{10}$. Adaptation to roles with experienced pregnancy conditions requires special programs, social and family assistance and support to reduce anxiety and increase the bond between mother and fetus ${ }^{11}$. 
Efforts to improve antenatal care in high-risk pregnancies to prevent negative impacts can be made through initial screening of the risk of hypertension and modification of antenatal care. Delays in detection and treatment will increase the incidence of complications in the perinatal. ${ }^{12}$. Monitoring and treatment for high-risk conditions needs to be focused on both the mother and the fetus, the so-called Dyad method ${ }^{13}$. The Dyad method is a method that involves the interaction between two people in certain situations such as the involvement of the mother and the fetus in an action to achieve the goal of the intervention. Antenatal care and monitoring performed on the mother and fetus can monitor as soon as possible the health condition experienced by both the mother and the fetus ${ }^{14}$. In research conducted by ${ }^{15}$ States that the Dyad Model for high-risk pregnancies needs to be carried out between the mother and the fetus considering that in high-risk pregnancies there are physiological disorders which are feared to interfere with the closeness of the relationship between the mother and the fetus. The Dyad model by providing interventions on the interaction between mother and fetus is best done to prevent complications that may occur in high-risk pregnancies, but this model needs to be developed by involving partner support to increase attachment and optimize one's ability to overcome problems or what is called Self Efficacy.

The involvement of a partner in the Dyad model is very important considering that the husband's pregnancy also feels anxiety, especially in a risky pregnancy. Research conducted 16 States that anxiety in a pregnancy can occur both to wives and husbands, anxiety that occurs in partners can result in attachment disorders that have an impact on the condition of fetal well-being. It is not enough just with the mother and the fetus, but support from the closest people, such as husbands, is needed to save the lives of mothers and babies. Partner support in the Dyad model is support for improving psychological conditions, partner adjustment and quality of life. ${ }^{17}$. The anxiety and psychological conditions felt by the couple need special intervention to increase calm and reduce the tension that occurs due to the disturbance in the pregnancy they are experiencing. Educational information during the antenatal period given to partners will be easier to understand and couples can plan for their pregnancy together. ${ }^{18}$. 


\section{METHOD}

\subsection{Research Design}

This research is a research using literature study method or literature review. Literature studies can be obtained from various sources including journals, books, documentation, the internet and libraries. The literature study method is a series of activities related to the method of collecting library data, reading and taking notes, and managing writing materials (Nursalam, 2016). The type of writing used is a literature review study that focuses on the results of writing related to the topic or a variable of writing.

\subsection{Data Collection Method}

The data used in this research comes from the results of research that have been conducted and published in national and international online journals. In conducting this research, the researchers conducted a search for research journals published on the internet using the Scopus, Ebsco, ProQuest and PubMed seach engines, with keywords: Dyad Model, Maternal Role, Self Efficacy and High Risk Pregnancy.

\subsection{Inclusion and Exclusion Criteria}

The inclusion and exclusion criteria of this Systematic Review are taken with several criteria which include problem, Intervention, Comparison, Outcome, Study Design, Time Period, Language, Type of Article and Content Theme.

In detail, the inclusion criteria that the researchers took are illustrated in the following table:

Table 2.1 The inclusion criteria for this literature are:

\begin{tabular}{l|l}
\hline Criteria & Inklusi \\
\hline Problem & $\begin{array}{l}\text { International journals from different databases and with } \\
\text { regard to research variables }\end{array}$ \\
\hline Intervention & Pemberian Dyad Model \\
\hline Comparison & There is no comparison factor \\
\hline Outcome & The influence or impact of giving the Dyad Model \\
\hline Study design & $\begin{array}{l}\text { Qualitative, Pra-ekspernimental and } \\
\text { Systematic/Literature review }\end{array}$ \\
\hline Time period & Articles published from 2019 to 2021 \\
\hline Language & English Language \\
\hline Article Type & Full text article \\
\hline Content theme & Dyad Model High Risk Pregnancy \\
\hline
\end{tabular}

After collecting data through the database, the researchers used the PRISMA (Preferre Reporting Items for Systematic Reviews and Meta Analysis) method to get the desired articles to be researched which are described in the chart below: 


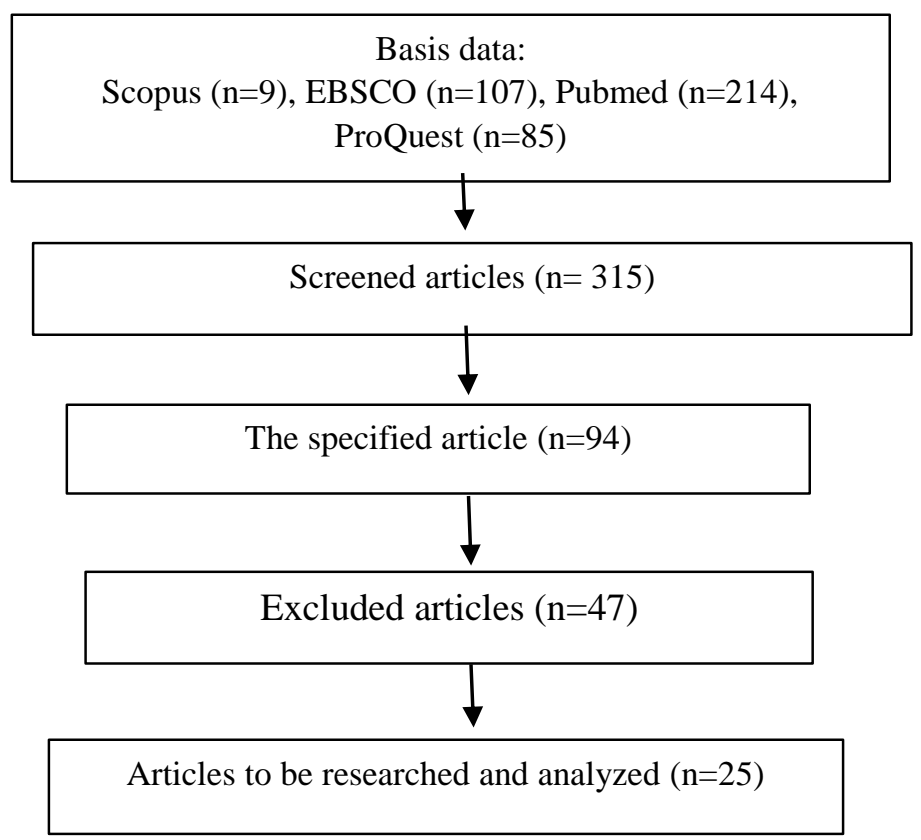

Literature review begins with the written material which is considered sequentially from the most relevant, relevant, and sufficiently relevant. Then read the abstract, each journal first to provide an assessment of whether the problems discussed are in accordance with what is going to be solved in a journal. Nothing about the important points and their relevance to the research problem. To keep from getting caught up in the plagiarism element, the author should also note the sources of information and include a bibliography. If indeed the information comes from other people's ideas or writing. Make notes, quotes, or information that are arranged systematically so that writing can easily be searched back if any time needed (Nursalam, 2020).

Each journal that has been selected based on the criteria, a conclusion is drawn that describes the Dyad Model explanation in maternity services. Before the author makes conclusions from several literature results, the author will identify in a brief summary form a table containing the author's name, year of writing, study design, samples, instruments (measuring instruments), and research results. After the writing results from much literature have been collected, the author will analyze the application of the Dyad Model in High-Risk Pregnancy.

\subsection{Metode Analisis Data}

Research journals that match the inclusion criteria are then collected and a journal summary is made including the name of the researcher, the year of publication of the journal, 
study design, research objectives, samples, instruments (measuring instruments) and a summary of the results or findings. The summary of the research journal is entered in a table sorted according to the title and year of publication of the journal and according to the format mentioned above.

To further clarify the abstract analysis and full text of the journal, read and observe it. The journal summary is then analyzed for the content contained in the research objectives and the results/ research findings. The analytical method used is using journal content analysis.

\section{RESULTS AND DISCUSSION}

\subsection{Results}

The literature review was conducted to find out about the Dyad Care Model in high-risk pregnancies which was carried out through the collection of existing literature. The literature was collected using a critical appraisal table to answer the objectives of the measurement and compare with the simple measurement results.

Table 3.1 Critical Appraisal Journals

\begin{tabular}{|c|c|c|c|}
\hline No & $\begin{array}{c}\text { Title of } \\
\text { Literature }\end{array}$ & Literature Analysis & Source \\
\hline 1 & $\begin{array}{l}\text { Anxiety, } \\
\text { depression, } \\
\text { dyadic } \\
\text { adjustment, and } \\
\text { attachment to the } \\
\text { fetus in } \\
\text { pregnancy: } \\
\text { Actor-partner } \\
\text { interdependence } \\
\text { mediation } \\
\text { analysis }\end{array}$ & $\begin{array}{l}\text { Providing services with the } \\
\text { Dyad model is able to } \\
\text { increase accountability and } \\
\text { service as well as improve } \\
\text { the results of care for } \\
\text { patients. }\end{array}$ & $\begin{array}{l}\text { Brandão, T., Brites, R., Pires, M., Hipólito, J., \& Nunes, } \\
\text { O. (2019). Anxiety, depression, dyadic adjustment, and } \\
\text { attachment to the fetus in pregnancy: Actor-partner } \\
\text { interdependence mediation analysis. Journal of Family } \\
\text { Psychology, } \\
\text { 33(3), 294-303. }\end{array}$ \\
\hline 2 & $\begin{array}{l}\text { Maternal } \\
\text { personality, } \\
\text { social support, } \\
\text { and changes in } \\
\text { depressive, } \\
\text { anxiety, and } \\
\text { stress symptoms } \\
\text { during pregnancy } \\
\text { and after } \\
\text { delivery: A } \\
\text { prospective- } \\
\text { longitudinal } \\
\text { study }\end{array}$ & $\begin{array}{l}\text { The support given to the } \\
\text { mother during the } \\
\text { pregnancy period will be } \\
\text { able to increase the mother's } \\
\text { knowledge, understanding } \\
\text { and insight so that there is } \\
\text { an increased understanding } \\
\text { of the health conditions of } \\
\text { herself and the fetus in the } \\
\text { womb. }\end{array}$ & $\begin{array}{l}19 \\
P L o S \text { ONE, 15(8 August), 1-18. } \\
\text { https://doi.org/10.1371/journal.pone.0237609 }\end{array}$ \\
\hline
\end{tabular}




\begin{tabular}{|c|c|c|c|}
\hline 3 & $\begin{array}{l}\text { Dyadic coping in } \\
\text { couples: A } \\
\text { conceptual } \\
\text { integration and a } \\
\text { review of the } \\
\text { empirical } \\
\text { literature. } \\
\text { Frontiers in } \\
\text { Psychology }\end{array}$ & $\begin{array}{l}\text { Pada Ibu hamil intervensi } \\
\text { Dyad dapat } \\
\text { mengoptimalkan } \\
\text { keterlibatan antara ibu dan } \\
\text { janin atau antara ibu dan } \\
\text { suami untuk mendapatkan } \\
\text { tndakan yang dilakukan } \\
\text { secara bersama-sama }\end{array}$ & $\begin{array}{l}\text { Falconier, M. K., \& Kuhn, R. (2019)., 10(MAR), 1-23. } \\
\text { https://doi.org/10.3389/fpsyg.2019.00571 }\end{array}$ \\
\hline 4 & $\begin{array}{l}\text { The Role of } \\
\text { Social Support in } \\
\text { Reducing } \\
\text { Anxiety Among } \\
\text { High Risk } \\
\text { Pregnant Women } \\
\text { in Third } \\
\text { Trimester }\end{array}$ & $\begin{array}{l}\text { Dyad bagian dari support } \\
\text { sosial atau dukungan sosial } \\
\text { yang dapat diambil dari } \\
\text { pasangan, orang terdekat } \\
\text { ataupun lingkungan }\end{array}$ & $\begin{array}{l}\text { Vidayanti, V., \& Pratiwi, D. A. A.(2019) } \\
\text { International Respati Health Conference (IRHC), } \\
\text { 1,610-615. }\end{array}$ \\
\hline 5 & $\begin{array}{l}\text { Social support- } \\
\text { a protective } \\
\text { factor for } \\
\text { depressed } \\
\text { perinatal } \\
\text { women? }\end{array}$ & $\begin{array}{l}\text { A good understanding will } \\
\text { be able to create thought } \\
\text { patterns and build positive } \\
\text { perceptions of pregnancy } \\
\text { and their abilities. Such } \\
\text { conditions can minimize } \\
\text { stressors experienced by } \\
\text { mothers, reduce the risk of } \\
\text { depression that can occur in } \\
\text { the antenatal and post-natal } \\
\text { periods and accelerate the } \\
\text { adaptation process to } \\
\text { achieve new roles. }\end{array}$ & $\begin{array}{l}\text { Milgrom, J., Hirshler, Y., Reece, J., Charlene, C. H., \& } \\
\text { Gemmill Alan, A. W. (2019). } \\
\text { International Journal of Environmental Research and } \\
\text { Public Health, 16(8). } \\
\text { https://doi.org/10.3390/ijerph16081426 }\end{array}$ \\
\hline 6 & 20 & $\begin{array}{l}\text { Social support that has a } \\
\text { positive impact on the } \\
\text { mother's understanding and } \\
\text { level of knowledge can also } \\
\text { increase self-confidence. } \\
\text { The high level of mother's } \\
\text { self-confidence has a } \\
\text { positive correlation with the } \\
\text { mother's ability to make } \\
\text { decisions about her own } \\
\text { health }\end{array}$ & $\begin{array}{l}\text { Narges Rafiei1, Mostafa Amini-Rarani2, Fahimeh Eizadi1, } \\
\text { Hassan Rafiey3, N. S. S. A. (2019) } \\
\text { Pacific AffairsInt J BioMed Public Health, 2(4), } \\
\text { 75-80. https://doi.org/10.2307/2752507 }\end{array}$ \\
\hline 7 & $\begin{array}{l}\text { Research } \\
\text { recommendations } \\
\text { from the national } \\
\text { institutes of } \\
\text { health workshop } \\
\text { on predicting, } \\
\text { preventing, and } \\
\text { treating } \\
\text { preeclampsia }\end{array}$ & $\begin{array}{l}\text { Monitoring and treatment } \\
\text { for high-risk conditions } \\
\text { needs to be focused on both } \\
\text { the mother and the fetus, } \\
\text { the so-called Dyad method }\end{array}$ & $\begin{array}{l}\text { Maric-Bilkan, C., Abrahams, V. M., Arteaga, S. S., } \\
\text { Bourjeily, G., Conrad, K. P., Catov, J. M., ... Roberts, J. } \\
\text { M. (2019) } \\
\text { Hypertension, 73(4), 757-766. } \\
\text { https://doi.org/10.1161/HYPERTENSIONAHA.118.11644 }\end{array}$ \\
\hline 8 & $\begin{array}{l}\text { Maternal health } \\
\text { care wearing } \\
\text { equipment based } \\
\text { on fetal } \\
\text { information } \\
\text { monitoring }\end{array}$ & $\begin{array}{l}\text { The Dyad method is a } \\
\text { method that involves the } \\
\text { interaction between two } \\
\text { people in certain situations } \\
\text { such as the involvement of } \\
\text { the mother and the fetus in }\end{array}$ & $\begin{array}{l}\text { Peng, J., Huang, Y., Yu, K., Fan, R., \& Zhou, J. (2019). } \\
\text { Journal of Infection and Public Health. } \\
\text { https://doi.org/10.1016/j.jiph.2019.07.031 }\end{array}$ \\
\hline
\end{tabular}




\begin{tabular}{|c|c|c|c|}
\hline & & $\begin{array}{l}\text { an action to achieve the } \\
\text { goal of the intervention. } \\
\text { Antenatal care and } \\
\text { monitoring performed on } \\
\text { the mother and fetus can } \\
\text { monitor as soon as possible } \\
\text { the health condition } \\
\text { experienced by both the } \\
\text { mother and the fetus }\end{array}$ & \\
\hline 9 & $\begin{array}{l}\text { Analysis of the } \\
\text { NANDA-I } \\
\text { taxonomy } \\
\text { "maternal-fetal } \\
\text { dyad" concept in } \\
\text { high-risk } \\
\text { pregnancy: } \\
\text { integrative } \\
\text { review }\end{array}$ & $\begin{array}{l}\text { The Dyad model for high- } \\
\text { risk pregnancies needs to be } \\
\text { carried out between the } \\
\text { mother and the fetus } \\
\text { considering that in } \\
\text { pregnancies there is a high } \\
\text { risk of physiological } \\
\text { disorders which are feared } \\
\text { to interfere with the } \\
\text { closeness of the relationship } \\
\text { between the mother and the } \\
\text { fetus. }\end{array}$ & $\begin{array}{l}\text { Gomes, R. C. M., Lopes, M. V. de O., Perrelli, J. G. A., } \\
\text { Pontes, C. M., Linhares, F. M. P., \& Mangueira, S. de O. } \\
\text { (2020). } \\
\text { Revista Brasileira de Enfermagem, 73(Suppl 4), } \\
\text { e20190649. https://doi.org/10.1590/0034-7167-2019-0649 }\end{array}$ \\
\hline 10 & $\begin{array}{l}\text { Dyadic coping, } \\
\text { marital } \\
\text { adjustment and } \\
\text { quality of life in } \\
\text { couples during } \\
\text { pregnancy: an } \\
\text { actor-partner } \\
\text { approach }\end{array}$ & $\begin{array}{l}\text { Dyad is a support to } \\
\text { improve psychological } \\
\text { condition, partner } \\
\text { adjustment and quality of } \\
\text { life }\end{array}$ & $\begin{array}{l}\text { Brandão, T., Brites, R., Hipólito, J., Pires, M., \& Nunes, } \\
\text { O. (2020). } \\
\text { Journal of Reproductive and Infant Psychology, 38(1), } \\
\text { 49-59. https://doi.org/10.1080/02646838.2019.1578950 }\end{array}$ \\
\hline 11 & $\begin{array}{l}\text { The Effect Of } \\
\text { Prenatal } \\
\text { Attachment } \\
\text { Health Education } \\
\text { With } \\
\text { Audiovisual On } \\
\text { Readiness To Be } \\
\text { Parents At } \\
\text { Sleman Primary } \\
\text { Health Care }\end{array}$ & $\begin{array}{l}\text { Educational information } \\
\text { during the antenatal period } \\
\text { given to partners will be } \\
\text { easier to understand and } \\
\text { couples can plan together } \\
\text { for their pregnancy }\end{array}$ & $\begin{array}{l}\text { Sariyani, D. (2019). The Effect Of Prenatal Attachment } \\
\text { Health Education With Audiovisual On Readiness To Be } \\
\text { Parents At Sleman Primary Health Care, 104-106. }\end{array}$ \\
\hline 12 & $\begin{array}{l}\text { Serratia } \\
\text { marcescens as a } \\
\text { cause of } \\
\text { unfavorable } \\
\text { outcome in the } \\
\text { twin pregnancy }\end{array}$ & $\begin{array}{l}\text { A good prenatal will be } \\
\text { able to minimize } \\
\text { complications for both } \\
\text { mother and baby }\end{array}$ & $\begin{array}{l}\text { Kljakić, D., Milosavljević, M. Z., Jovanović, M., Popović, } \\
\text { V. Č., \& Raičević, S. (2021). } \\
\text { Open Medicine (Poland), 16(1), 81-86. } \\
\text { https://doi.org/10.1515/med-2021-0205 }\end{array}$ \\
\hline 13 & $\begin{array}{l}\text { Experiences of } \\
\text { the maternal role } \\
\text { and support in } \\
\text { mothers with } \\
\text { cognitive } \\
\text { limitations who } \\
\text { have children in } \\
\text { placement }\end{array}$ & $\begin{array}{l}\text { failure to become a mother } \\
\text { can lead to depression and } \\
\text { have an impact on the } \\
\text { mother's ability to maintain } \\
\text { pregnancy and child care }\end{array}$ & $\begin{array}{l}\text { Janeslätt, G., Jöreskog, K., Lindstedt, H., \& Adolfsson, P. } \\
\text { (2019). } \\
\text { Child and Family Social Work, 24(4), 494-502. } \\
\text { https://doi.org/10.1111/cfs.12629 }\end{array}$ \\
\hline 14 & $\begin{array}{l}\text { Mother- } \\
\text { Adolescent } \\
\text { Conflict }\end{array}$ & $\begin{array}{l}\text { The mother's ability to } \\
\text { adjust roles and manage } \\
\text { problems can reduce }\end{array}$ & $\begin{array}{l}\text { Van Bommel, D. M. H., Van der Giessen, D., Van der } \\
\text { Graaff, J., Meeus, W. H. J., \& Branje, S. J. T. } \\
\text { (2019). }\end{array}$ \\
\hline
\end{tabular}




\begin{tabular}{|c|c|c|c|}
\hline & $\begin{array}{l}\text { Interaction } \\
\text { Sequences: The } \\
\text { Role of Maternal } \\
\text { Internalizing } \\
\text { Problems }\end{array}$ & $\begin{array}{l}\text { various problems } \\
\text { experienced during her } \\
\text { pregnancy period }\end{array}$ & $\begin{array}{l}\text { Journal of Research on Adolescence, 29(4), 1001-1018. } \\
\text { https://doi.org/10.1111/jora.12441 }\end{array}$ \\
\hline 15 & $\begin{array}{l}\text { Effects of a } \\
\text { supportive } \\
\text { program on } \\
\text { uncertainty, } \\
\text { anxiety, and } \\
\text { maternal-fetal } \\
\text { attachment in } \\
\text { women with } \\
\text { high-risk } \\
\text { pregnancy. }\end{array}$ & $\begin{array}{l}\text { Adaptation to roles with } \\
\text { experienced pregnancy } \\
\text { conditions requires special } \\
\text { programs, social and family } \\
\text { assistance and support to } \\
\text { reduce anxiety and increase } \\
\text { the bond between mother } \\
\text { and fetus. }\end{array}$ & $\begin{array}{l}\text { Kim, H. J., \& Chun, N. (2020). } \\
\text { Korean Journal of Women Health Nursing, 26(2), 180- } \\
\text { 190. https://doi.org/10.4069/kjwhn.2020.06.17 }\end{array}$ \\
\hline 16 & $\begin{array}{l}\text { Maternal Role: A } \\
\text { Concept Analysis }\end{array}$ & $\begin{array}{l}\text { Maternal Role is the role of } \\
\text { a mother where this new } \\
\text { role is not an easy thing for } \\
\text { women, and it needs } \\
\text { mentoring, social and } \\
\text { family support or mentoring } \\
\text { so that the process } \\
\text { experienced can run well. }\end{array}$ & $\begin{array}{l}\text { Shrestha, S., Adachi, K., A Petrini, M., \& Shrestha, S. } \\
\text { (2019). } \\
\text { Journal of Midwifery and Reproductive Health, O(0), 1- } \\
\text { 10. https://doi.org/10.22038/jmrh.2019.31797.1344 }\end{array}$ \\
\hline 17 & $\begin{array}{l}\text { Factors affecting } \\
\text { utilization of } \\
\text { antenatal care in } \\
\text { Ethiopia : A } \\
\text { systematic } \\
\text { review and meta- } \\
\text { analysis. }\end{array}$ & $\begin{array}{l}\text { Care during the antenatal } \\
\text { period is influenced by the } \\
\text { level of education of the } \\
\text { mother and husband, } \\
\text { planned pregnancy, } \\
\text { exposure to social media, } \\
\text { economic status and } \\
\text { distance to antenatal care }\end{array}$ & $\begin{array}{l}\text { Id, T. T., Chojenta, C., Smith, R., \& Loxton, D. (2019). } \\
\text { Factors affecting utilization of antenatal care in Ethiopia : } \\
\text { A systematic review and meta- analysis, 1-24. }\end{array}$ \\
\hline 18 & $\begin{array}{l}\text { Stress, } \\
\text { Depressive } \\
\text { Symptoms, and } \\
\text { Maternal Self- } \\
\text { Efficacy in First- } \\
\text { Time Mothers: } \\
\text { Modelling and } \\
\text { Predicting } \\
\text { Change across } \\
\text { the First Six } \\
\text { Months of } \\
\text { Motherhood }\end{array}$ & $\begin{array}{l}\text { Self-Efficacy is a belief, } \\
\text { perception and belief in } \\
\text { one's abilities }\end{array}$ & $\begin{array}{l}\text { Law, K. H., Dimmock, J., Guelfi, K. J., Nguyen, T., } \\
\text { Gucciardi, D., \& Jackson, B. (2019). } \\
\text { Applied Psychology: Health and Well-Being, 11(1), 126- } \\
\text { 147. https://doi.org/10.1111/aphw.12147 }\end{array}$ \\
\hline 19 & $\begin{array}{l}\text { Professional self- } \\
\text { efficacy and job } \\
\text { satisfaction: The } \\
\text { mediator role of } \\
\text { work design }\end{array}$ & $\begin{array}{l}\text { Good self-esteem will } \\
\text { reduce individual stress and } \\
\text { be able to improve the } \\
\text { quality of maternal health } \\
\text { during pregnancy. Self- } \\
\text { efficacy is related to the } \\
\text { success of the mother in the } \\
\text { perinatal period }\end{array}$ & $\begin{array}{l}\text { Bargsted, M., Ramírez-Vielma, R., \& Yeves, J. (2019). } \\
\text { Revista de Psicologia Del Trabajo y de Las } \\
\text { Organizaciones, 35(3), 157-163. } \\
\text { https://doi.org/10.5093/jwop2019a18 }\end{array}$ \\
\hline 20 & $\begin{array}{l}\text { Increasing of } \\
\text { Pregnancy } \\
\text { Education on the } \\
\text { Self Efficacy of } \\
\text { Pregnant Women }\end{array}$ & $\begin{array}{l}\text { Educational given during } \\
\text { pregnancy significantly } \\
\text { increases self-esteem, } \\
\text { whether the mother is }\end{array}$ & $\begin{array}{l}\text { Chalid, M. T., \& Hasanuddin, U. (2019). } \\
\text { International Journal of Sciences : Increasing of Pregnancy } \\
\text { Education on the Self Efficacy of Pregnant Women in } \\
\text { Group, (February). }\end{array}$ \\
\hline
\end{tabular}




\begin{tabular}{|c|c|c|c|}
\hline & $\begin{array}{l}\text { in Groups } \\
\text { Accompanied by } \\
\text { Their Husbands } \\
\text { and Groups } \\
\text { Unaccompanied }\end{array}$ & $\begin{array}{l}\text { accompanied by her } \\
\text { husband or not }\end{array}$ & \\
\hline 21 & $\begin{array}{l}\text { Intervention } \\
\text { intended to } \\
\text { improve public } \\
\text { health } \\
\text { professionals' } \\
\text { self-efficacy in } \\
\text { their efforts to } \\
\text { detect and } \\
\text { manage perinatal } \\
\text { depressive } \\
\text { symptoms among } \\
\text { Thai women: A } \\
\text { mixed-methods } \\
\text { study }\end{array}$ & $\begin{array}{l}\text { Self-Efficacy can be } \\
\text { influenced by four } \\
\text { important sources, namely } \\
\text { performance achievement, } \\
\text { experience, verbal } \\
\text { persuasion and sources of } \\
\text { information }\end{array}$ & $\begin{array}{l}\text { Phoosuwan, N., Lundberg, P. C., Phuthomdee, S., \& } \\
\text { Eriksson, L. (2020). } \\
\text { BMC Health Services Research, 20(1), 1-12. } \\
\text { https://doi.org/10.1186/s12913-020-5007-z }\end{array}$ \\
\hline 22 & $\begin{array}{l}\text { Anxiety and Fear } \\
\text { Level toward } \\
\text { Childbirth among } \\
\text { Primigravida } \\
\text { versus } \\
\text { Multigravida }\end{array}$ & $\begin{array}{l}\text { The low self efficacy will } \\
\text { cause anxiety in the mother. } \\
\text { This is because pregnant } \\
\text { women experience anxiety } \\
\text { in facing their new roles, } \\
\text { especially primigravida } \\
\text { mothers who have no } \\
\text { experience }\end{array}$ & $\begin{array}{l}\text { Mahmoud, T. M., Obstetrics, A., Nursing, G., \& Nursing, } \\
\text { F. (2019). } \\
\text { * Madiha Mohamed Tosson, ** Azza Mohamed Elsayed } \\
\text { Atwa , 8(2), 36-44. https://doi.org/10.9790/1959- } \\
0802023644\end{array}$ \\
\hline 23 & $\begin{array}{l}\text { Professional self- } \\
\text { efficacy and job } \\
\text { satisfaction: The } \\
\text { mediator role of } \\
\text { work design. }\end{array}$ & $\begin{array}{l}\text { Good self-esteem will } \\
\text { reduce individual stress and } \\
\text { be able to improve the } \\
\text { quality of maternal health } \\
\text { during pregnancy. Self- } \\
\text { efficacy is related to the } \\
\text { success of the mother in the } \\
\text { perinatal period }\end{array}$ & $\begin{array}{l}\text { Bargsted, M., Ramírez-Vielma, R., \& Yeves, J. (2019). } \\
\text { Revista de Psicologia Del Trabajo y de Las } \\
\text { Organizaciones, 35(3), 157-163. } \\
\text { https://doi.org/10.5093/jwop2019a18 }\end{array}$ \\
\hline 24 & $\begin{array}{l}\text { Impact of } \\
\text { maternal HIV } \\
\text { infection on } \\
\text { pregnancy } \\
\text { outcomes in } \\
\text { southwestern } \\
\text { China - A } \\
\text { hospital registry } \\
\text { based study }\end{array}$ & $\begin{array}{l}\text { HIV-infected pregnancies } \\
\text { can cause perinatal } \\
\text { disorders associated with } \\
\text { the birth of babies in poor } \\
\text { conditions, namely preterm } \\
\text { birth, low birth weight, and } \\
\text { intrauterine fetal growth } \\
\text { disturbances. Fetuses were } \\
\text { born to pregnant women } \\
\text { who are HIV positive have } \\
\text { the potential to experience } \\
\text { low APGAR scores as a } \\
\text { result of asphyxia that } \\
\text { occurs because maternal } \\
\text { infection inhibits surfactant } \\
\text { synthesis and secretion. }\end{array}$ & $\begin{array}{l}\text { Yang, M., Wang, Y., Chen, Y., Zhou, Y., \& Jiang, Q. } \\
\text { (2019). } \\
\text { Epidemiology and Infection, } 147 . \\
\text { https://doi.org/10.1017/S0950268818003345 }\end{array}$ \\
\hline 25 & $\begin{array}{l}\text { Impact of } \\
\text { overweight and } \\
\text { obesity on } \\
\text { pregnancy } \\
\text { outcomes in }\end{array}$ & $\begin{array}{l}\text { Counseling before or during } \\
\text { pregnancy can reduce the } \\
\text { risk of pregnancy disorders } \\
\text { such as macrosomia and }\end{array}$ & $\begin{array}{l}\text { Machado, C., Monteiro, S., \& Oliveira, M. J. (2020). } \\
\text { Archives of Endocrinology and Metabolism, 64(1), 45-51. } \\
\text { https://doi.org/10.20945/2359-3997000000178 }\end{array}$ \\
\hline
\end{tabular}




\begin{tabular}{|l|l|l|l|}
\hline $\begin{array}{l}\text { women with } \\
\text { gestational } \\
\text { diabetes - } \\
\text { Results from a } \\
\text { retrospective } \\
\text { multicenter study }\end{array}$ & $\begin{array}{l}\text { large of gertational age } \\
\text { (LGA). }\end{array}$ & \\
\end{tabular}

The results of the analysis of 25 literature states that either the Ha or alternative hypothesis is accepted, which means that there is an effect of the Dyad Model on nursing care in high-risk pregnancies.

\subsection{Discussion}

The results of the review of 25 journals are categorized into 4 groups with details, the first group is a journal that focuses on the Dyad Model and 7 titles of social support, the second group of journals that discuss high-risk pregnancy is 6 titles, the third group of journals that discuss maternal role as much 6 titles and the fourth group of journals discussing Self Efficacy as many as 6 titles.

The dyad Model is a method of giving intervention that involves the interaction between two people in certain situations such as the involvement of the mother and fetus or husband and wife in an action to achieve the goal of the intervention. ${ }^{17}$. Providing services with the Dyad model is able to increase accountability and service as well as improve the results of care for patients. The Dyad Model can be applied to mothers with a high risk of pregnancy by optimizing the interuse between the mother and the partner or husband in providing interventions. The provision of interventions will be more optimal and provide mutual support in increasing understanding of pregnancy, understanding the role of parents, adapting roles and increasing confidence in their ability to maintain the health of their pregnancy. ${ }^{16}$.

Pregnancy with a high risk condition is a pregnancy with complications that result in health problems for both the mother and the fetus. High risks in pregnancy include pregnancy with HIV positive, diabetes mellitus, hypertension in pregnancy, obesity, multiple pregnancies, pregnancies that are too young or too old ${ }^{1}$. High-risk pregnancy conditions can cause complications to both the mother and the fetus during the perinatal period. Women who experience high-risk pregnancy conditions must have the resilience to struggle in facing their new roles or maternal roles.

Maternal Role is the role of a mother where this new role is not an easy thing for women, and the need for assistance, social and family support or escort so that the process is experienced can run well ${ }^{21}$. 
The dyad model is an intervention model that can be provided by involving two people. This intervention is the development of social support or social support. In pregnant women, Dyad intervention can optimize involvement between mother and fetus or between mother and husband to get action done together. ${ }^{22}$ This intervention is carried out with the aim of increasing comfort, reducing psychological anxiety, increasing self-potential and preventing the emergence of various kinds of disorders that can occur during the period of maternal pregnancy. Dyad is part of social support or social support that can be taken from a partner, loved ones or the environment ${ }^{23}$

The support given to the mother during the pregnancy period will be able to increase the mother's knowledge, understanding and insight so that there is an increased understanding of the health conditions of herself and the fetus in the womb. ${ }^{19}$. A good understanding will be able to create thought patterns and build positive perceptions of pregnancy and their abilities. Such conditions can minimize stressors experienced by mothers, reduce the risk of depression that can occur in the antenatal and post-natal periods and accelerate the adaptation process to achieve new roles. ${ }^{24}$.

Social support that has a positive impact on the mother's understanding and level of knowledge is also able to increase self-confidence or what is called self-efficacy. Self-Efficacy can be increased through increasing knowledge of pregnant women. And understanding of their health conditions during pregnancy will be able to reduce individual stressors during pregnancy and prepare themselves to become mothers. Research conducted by ${ }^{25}$ Mentioned that the education given during pregnancy significantly increases self-Efficacy, whether the mother is accompanied by her husband or not. <sup >25</sup> [25](Chalid \& Hasanuddin, 2019)(Chalid \& Hasanuddin, 2019)(Chalid \& Hasanuddin, 2019). Self-Efficacy can be influenced by four important sources, namely performance achievement, experience, verbal persuasion and sources of information ${ }^{26}$. Achieving these components properly will increase the confidence and motivation of pregnant women in carrying out maternal roles. The low self efficacy will cause anxiety in the mother. This is because pregnant women experience anxiety in facing their new roles, especially primigravida mothers who have no experience ${ }^{27}$.

The high level of mother's self-confidence has a positive correlation with the mother's ability to make decisions about her own health ${ }^{20}$. The mother is able to make decisions about her health condition by considering the safety aspects of both herself and the fetus in the womb. What 
actions will be taken, how to plan for her pregnancy and the solution to the problems she is experiencing will be decided.

\section{Conclusion}

The dyad model is part of the intervention from social support or social support. The development of this model led to an intervention in the form of an action that involved two people. Two people can be a mother with a fetus or a mother and a father when the activity is applied to a pregnancy.

Providing social support or a good Dyad model will be able to reduce the level of anxiety when the mother is facing pregnancy, childbirth and the period of breastfeeding. This ability can reduce stressors which have positive implications for the mother's ability to adapt to her new role or maternal role.

Social support in the form of a Dyad care model is also able to increase understanding of pregnant women so that mothers become more confident in the pregnancy period, face childbirth and achieve new roles. The condition in which the mother is more confident will increase the mother's ability to make decisions about her health status.

\section{Suggestion}

The need for efforts to increase the understanding of the spouse or family of the importance of social support in providing services, especially for pregnant women. It is necessary to develop the provision of interventions by involving the support of partners or families in providing nursing care to pregnant women both at the clinical and community levels. It is necessary to establish services for pregnant women in the form of prenatal classes with the development of a Dyad Care program that optimizes support from husbands or partners in a structured manner.

\section{REFERENCES}

1. Vaghela N. Study of Pregnancy Outcome in Various High-Risk Pregnancies in Tertiary Care Hospital. Int J Med Biomed Stud. 2019;3(12):38-42. doi:10.32553/ijmbs.v3i12.793

2. $\quad$ WHO. Maternal Mortality : Level and Trends 2000 to 2017.; 2019.

https://www.who.int/reproductivehealth/publications/maternal-mortality-2000-2017/en/.

3. Rajbanshi S, Norhayati MN, Hazlina NHN. High-risk pregnancies and their association 
with severe maternal morbidity in Nepal: A prospective cohort study. PLoS One. 2021;15(12 December):1-14. doi:10.1371/journal.pone.0244072

4. Santos S, Voerman E, Amiano P, et al. Impact of maternal body mass index and gestational weight gain on pregnancy complications: an individual participant data metaanalysis of European, North American and Australian cohorts. BJOG An Int J Obstet Gynaecol. 2019;126(8):984-995. doi:10.1111/1471-0528.15661

5. S S. A review article- gestational diabetes mellitus. Endocrinol Int J. 2019;7(1):26-39. doi:10.15406/emij.2019.07.00238

6. Røhder K, Væver MS, Aarestrup AK, Jacobsen RK, Smith-Nielsen J, Schiøtz ML. Maternal-fetal bonding among pregnant women at psychosocial risk: The roles of adult attachment style, prenatal parental reflective functioning, and depressive symptoms. PLoS One. 2020;15(9 September 2020):1-19. doi:10.1371/journal.pone.0239208

7. Isaacs NZ, Andipatin MG. A systematic review regarding women's emotional and psychological experiences of high-risk pregnancies. BMC Psychol. 2020;8(1):1-11. doi:10.1186/s40359-020-00410-8

8. Li C, Sun X, Li Q, Sun Q, Wu B, Duan D. Role of psychotherapy on antenatal depression, anxiety, and maternal quality of life: A meta-analysis. Medicine (Baltimore). 2020;99(27):e20947. doi:10.1097/MD.0000000000020947

9. Janeslätt G, Jöreskog K, Lindstedt H, Adolfsson P. Experiences of the maternal role and support in mothers with cognitive limitations who have children in placement. Child Fam Soc Work. 2019;24(4):494-502. doi:10.1111/cfs.12629

10. Van Bommel DMH, Van der Giessen D, Van der Graaff J, Meeus WHJ, Branje SJT. Mother-Adolescent Conflict Interaction Sequences: The Role of Maternal Internalizing Problems. J Res Adolesc. 2019;29(4):1001-1018. doi:10.1111/jora.12441

11. Kim HJ, Chun N. Effects of a supportive program on uncertainty, anxiety, and maternalfetal attachment in women with high-risk pregnancy. Korean J Women Heal Nurs. 2020;26(2):180-190. doi:10.4069/kjwhn.2020.06.17

12. Tolu LB, Yigezu E, Urgie T, Feyissa GT. Maternal and perinatal outcome of preeclampsia without severe feature among pregnant women managed at a tertiary referral hospital in urban Ethiopia. PLoS One. 2020;15(4):1-10. doi:10.1371/journal.pone.0230638

13. Maric-Bilkan C, Abrahams VM, Arteaga SS, et al. Research recommendations from the 
national institutes of health workshop on predicting, preventing, and treating preeclampsia. Hypertension. 2019;73(4):757-766.

doi:10.1161/HYPERTENSIONAHA.118.11644

14. Peng J, Huang Y, Yu K, Fan R, Zhou J. Maternal health care wearing equipment based on fetal information monitoring. J Infect Public Health. 2019. doi:10.1016/j.jiph.2019.07.031

15. Gomes RCM, Lopes MV de O, Perrelli JGA, Pontes CM, Linhares FMP, Mangueira S de O. Analysis of the NANDA-I taxonomy "maternal-fetal dyad" concept in high-risk pregnancy: integrative review. Rev Bras Enferm. 2020;73(Suppl 4):e20190649. doi:10.1590/0034-7167-2019-0649

16. Brandão T, Brites R, Pires M, Hipólito J, Nunes O. Anxiety, depression, dyadic adjustment, and attachment to the fetus in pregnancy: Actor-partner interdependence mediation analysis. J Fam Psychol. 2019;33(3):294-303. doi:10.1037/fam0000513

17. Brandão T, Brites R, Hipólito J, Pires M, Nunes O. Dyadic coping, marital adjustment and quality of life in couples during pregnancy: an actor-partner approach. J Reprod Infant Psychol. 2020;38(1):49-59. doi:10.1080/02646838.2019.1578950

18. Sariyani D. The Effect Of Prenatal Attachment Health Education With Audiovisual On Readiness To Be Parents At Sleman Primary Health Care. 2019:104-106.

19. Asselmann E, Kunas SL, Wittchen HU, Martini J. Maternal personality, social support, and changes in depressive, anxiety, and stress symptoms during pregnancy and after delivery: A prospective-longitudinal study. PLoS One. 2020;15(8 August):1-18. doi:10.1371/journal.pone.0237609

20. Narges Rafiei1, Mostafa Amini-Rarani2, Fahimeh Eizadi1, Hassan Rafiey3 NSSA. Social support and its role the prevention of depression and anxiety during pregnancy in Turkmen women. Pacific Aff J BioMed Public Heal. 2019;2(4):75-80. doi:10.2307/2752507

21. Shrestha S, Adachi K, A Petrini M, Shrestha S. Maternal Role: A Concept Analysis. J Midwifery Reprod Heal. 2019;0(0):1-10. doi:10.22038/jmrh.2019.31797.1344

22. Falconier MK, Kuhn R. Dyadic coping in couples: A conceptual integration and a review of the empirical literature. Front Psychol. 2019;10(MAR):1-23. doi:10.3389/fpsyg.2019.00571

23. Vidayanti V, Pratiwi DAA. the Role of Social Support in Reducing Anxiety Among High 
Risk Pregnant Women in Third Trimester. Int Respati Heal Conf. 2019;1:610-615.

24. Milgrom J, Hirshler Y, Reece J, Charlene CH, Gemmill Alan AW. Social support-a protective factor for depressed perinatal women? Int J Environ Res Public Health. 2019;16(8). doi:10.3390/ijerph16081426

25. Chalid MT, Hasanuddin U. Increasing of Pregnancy Education on the Self Efficacy of Pregnant Women in Groups Accompanied by Their Husbands and Groups Unaccompanied International Journal of Sciences : Increasing of Pregnancy Education on the Self Efficacy of Pregnant Women in Group. 2019;(February).

26. Phoosuwan N, Lundberg PC, Phuthomdee S, Eriksson L. Intervention intended to improve public health professionals' self-efficacy in their efforts to detect and manage perinatal depressive symptoms among Thai women: A mixed-methods study. BMC Health Serv Res. 2020;20(1):1-12. doi:10.1186/s12913-020-5007-z

27. Mahmoud TM, Obstetrics A, Nursing G, Nursing F. Anxiety and Fear Level toward Childbirth among Primigravida versus Multigravida * Madiha Mohamed Tosson , ** Azza Mohamed Elsayed Atwa ,. 2019;8(2):36-44. doi:10.9790/1959-0802023644 